\title{
REDISCUTINDO A ESTABILIZAÇÃO, PELO DECURSO TEMPORAL, DOS ATOS ADMINISTRATIVOS SUPOSTAMENTE VICIADOS'
}

\author{
FÁBIO BARBALHO LEITE ${ }^{2}$
}

1. ALGUMAS CONSIDERAÇÕES DE ORDEM TEÓRICA, 2. OS NÓS; 3. PANORAMA DAS POSIÇÕES DOUTRINÁRIAS E JURISPRUDENCIAIS ACERCA DO TEMA; 4. DESCONSTRUINDO PARA CONSTRUIR; 5. PARA UMA TENTATIVA DE SISTEMATIZAÇÃO DAS SOLUÇÕES OFERTÁVEIS AO PROBLEMA EM FOCO: a) A estabilização dos atos administrativos viciados se dá com a operação da prescrição: primeiro fundamento; b) A estabilização dos atos administrativos viciados se dá com a operação da prescrição: segundo fundamento; c) Competência legislativa da União Federal e correlações com as competências legislativas do demais entes federativos; d) Os prazos; 6. ENFIM...

\section{Considerações introdutórias}

Simplória e vã é a idéia de que a produção de atos administrativos, como dos atos jurídicos em geral, somente poder-se-ia efetivar mediante a observância do

1 Neste trabalho, retomo pontualmente tema desenvolvido com mais fôlego em minha Dissertação de Mestrado "Os Regimes Jurídicos de Invalidação dos Atos Administrativos Viciados", PUC/SP, 2001; no prelo. Foi ele, este trabalho, originalmente apresentado como exposição no I Fórum de Direito Público da Escola Superior de Magistratura do Rio Grande do Norte e, recentemente, em sua versão original, publicado pela referida Escola em coletânea intitulada "Estudos em Direito Público", Natal, 2002. Esta versāo do trabalho parte daquela, mas é enriquecida com argumentação e referência bibliografia mais detidas, e alterada em alguns pontos relevantes, notadamente no que atina com o prazo prescritivo de estabilização dos atos administrativos viciados mediante suposta má fé, hipótese também mais problematizada nesta versão e, enfim, a reflexão é normativamente atualizada em face do atual Código Civil.

2 Mestre em Direito do Estado (PUC/SP), Professor de Direito do Estado na Especialização de Direito do Estado da Faculdade de Direito de Itu (FADITU/SP), Advogado, e-mail: fabiobl@manesco.com.br.

R. Dir. Adm.,

Rio de Janeiro, 231: 93-115,

Jan./Mar. 2003 
regramento procedimental e material (conteúdo) presente em normas jurídicas superiores. Essa noção mais difundida de validade, esposa da concepção de um mundo perfeito para a produção jurídica, quando confrontada com a realidade da operação do sistema jurídico não torna compreensível o fato encontradiço da criação de atos administrativos, assim como atos jurídicos em geral, que, nada obstante qualificáveis como tais, apresentam objetivos descompassos ora em face de sua regência procedimental, ora em face de sua regência de fundo (matéria), quando não ambas.

Em suma, essa teoria, dita simplória, assim o é, pois, enclausurada em uma concepção exageradamente idealista do ordenamento jurídico, alheia-se das contingências que a operação do sistema jurídico produz, dentre elas: a produção de direito sem observância do direito. Isso que, para essa noção da produção jurídica dita vã, soa como um paradoxo no mínimo angustiante, é, todavia, fato sequer incomum e os vários procedimentos administrativos e judiciais de invalidação de atos administrativos viciados estão aí para testemunhar a freqüência do fenômeno. Se os atos administrativos somente fossem produzidos mediante estrita observância das normas juridicas que thes são superiores, se seus efeitos juridicos somente se deflagrassem naquelas hipóteses de impecável observância das disposições normativas que lhes regem a expedição dos atos administrativos, fácil e irretorquivelmente concluir-se-ia que o remédio constitucional do Mandado de Segurança seria uma grande inutilidade jurídica, dada a (suposta) impossibilidade teórica e prática da configuração dos pressupostos fáticos de sua procedência.

Mas todos sabemos que nem de longe as coisas no mundo real do direito são assim, e vã é a teoria que não nos habilita a compreender a realidade de seu objeto e sobre ela intervir produtivamente.

Diante disso, se a doutrina juridica pretende ser um conhecimento prático portanto, que possa ofertar uma compreensão, não somente abstrata e ideal, mas também uma racionalidade prática do fenômeno jurídico mirando soluções de problemas concretos - , deve procurar não só descrever o sistema jurídico em uma estática ideal, mas também desenvolver instrumentos teóricos e técnicos que habilitem os aplicadores do direito à solução dos tormentosos problemas envolvidos no tratamento jurídico dos atos administrativos viciados.

A pesquisa em torno dos efeitos estabilizantes do decurso temporal, tema informado por normas jurídicas de indiscutível conteúdo ético, sobre os atos administrativos supostamente ${ }^{3}$ viciados é um dos caminhos de necessário percurso. O tempo, porque ao seu escoamento normas jurídicas atribuem efeitos invulnerabilizantes do questionamento da validade dos atos administrativos, importa em estabilização dos

3 Com a expressão supostamente, chamo a atenção para o fato de que a invalidade dos atos administrativos (=desconstituição de sua validade) somente surge após a produção do ato jurídico invalidante, o que pressupõe, de direito, um específico processo administrativo ou judicial. Para aprofundar, ver meu "Os Regimes Jurídicos de Invalidação dos Atos Administrativos Viciados", Dissertação de Mestrado, PUC/SP. 2001, especialmente os tópicos 11.4.3, III.4 e V.4.2. Ver também "O Procedimento de Invalidaçāo dos Alos Administrativos", Mônica Martins Toscano, Dissertação de Mestrado, PUC/SP, 2000. 
vícios alegadamente configuráveis quer no processo de produção, quer nos próprios atos administrativos. Cabe o sublinhado: por estabilização é aqui considerado o fenômeno de invulnerabilidade dos atos jurídicos à constituição da invalidade (invalidação), não à revogação ${ }^{4}$

Tentemos ver como isto se dá.

\section{Os nós}

Figuremos algumas hipóteses...

Um contrato administrativo foi produzido mediante procedimento licitatório do qual um participante foi alijado, quando do juízo de habilitação, mediante decisão administrativa desmotivada (afronta ao dever de motivação dos atos administrativos, genérica e implicitamente previsto no Texto Constitucional a partir da confluência, entre tantos outros, dos arts. $1^{\circ}$ - princípio republicano $-, 5^{\circ}, \mathrm{XXXV}-$ inafastabilidade do controle jurisdicional - , LIV — direito à ampla defesa e contraditório —, LV — devido processo legal —, 37, caput - publicidade —, 93, IX — motivação das decisões judiciais - e X - motivação das decisões administrativas do Judiciário -; Lei n. 9784/99, art. $2^{\circ}$, parágrafo único, VII).

Perguntemo-nos: dez anos após formalizado e executado integralmente e a contento o contrato administrativo acima idealizado, permaneceria a possibilidade de sua invalidação administrativa ou judicial com base no vício procedimental constatável no procedimento de sua produção (certame público)?

Um servidor público foi demitido por ato administrativo com fundamento (descrição de seus pressupostos de fato e de direito) inidôneo (imaginenos que o fundamento externado configurasse hipótese de pena disciplinar de suspensão apenas; logo configurável vício material quanto à motivação). Quinze anos após a edição desse ato administrativo continuaria possível sua invalidação pelo interessado?

Um condicionamento administrativo expedido concretamente em face de um imóvel urbano e que, mais que uma conformação do conteúdo do direito de propriedade imobiliária urbana, importe em parcial sacrifício desse direito (portanto, em uma expropriação velada sem qualquer indenização) continuaria passível de invalidação passados treze anos de sua expedição?

Um servidor público nomeado sem prévia classificação em concurso público poderia ter sua nomeação invalidada vinte e cinco anos após sua investidura inicial? E se aposentado, sua aposentadoria poderia ser igualmente invalidada sob fundamento do mesmo vício?

4 Não é que se afirme aí a impossibilidade de estabilização de atos administrativos perante a competência revogadora, cumpre apenas a ressalva o sentido de avisar que o trabalho em curso ocupa-se exclusivamente da estabilização dos atos administrativos em face das competências invalidantes (administrativa e jurisdicional). A revogação (considerada no sentido estrito de revisão do ato administrativo em vista de razões de oportunidade e conveniência, jamais sobre o aspecto da validade), pois, que tem outros pressupostos, não é aqui problematizada. 
Como vemos, todos esses casos colocam, entre outros, o problema da duração no tempo da competência administrativa ou judicial de invalidação de atos administrativos viciados. Adiante, após um sintético panorama das respostas doutrinárias e jurisprudenciais mais difundidas, apresentarei as soluções teóricas ${ }^{5}$ que tenho para mim como mais fiéis tanto ao nosso direito positivo, quanto aos limites que integram sua organização lógica (sintática).

\section{Panorama das posições doutrinárias e jurisprudenciais acerca do tema}

Há quem diga que a invalidação de atos administrativos supostamente danosos ao interesse público seria imprescritivel em face da CF, art. $37, \S 5^{\circ 6}$. Outros falam que a imprescritibilidade compareceria quanto àqueles atos administrativos com vício de má fé e entendem encontrar fundamento normativo para essa exegese quer no princípio da moralidade administrativa (CF, art. 37, caput), quer, ao menos quanto aos atos administrativos federais, na Lei de Processo Administrativo Federal, Lei n. 9.784 , de 29 de janeiro de 1999 , art. $54^{7}$.

Segundo jurisprudência do Supremo Tribunal Federal, os atos administrativos viciados poderiam ser invalidados pela própria Administração a qualquer tempo, porque deles não emanariam direitos para ninguém ${ }^{8}$. E quanto aos casos de desapropriação indireta, o Superior Tribunal de Justiça entende que os atos administrativos nela implicados poderiam ser invalidados até dez ou vinte anos (respectivamente entre presentes e ausentes), porquanto, assim não o fosse, a aplicação do prazo qüinqüenal, genericamente previsto no Dec. 20.910/32, art. $1^{\circ}$, importaria em usucapião extraordinário, sem que explícita norma assim determinasse ${ }^{9}$.

WEIDA ZANCANER ${ }^{10}$ entende que se o vício residente em um ato administrativo puder ser escoimado uma vez repetido o ato administrativo (por exemplo, a ausência da manifestação de um órgão que possa ser posteriormente suprida com

5 Não cuidarei de focar a resposta para cada um desses hipotéticos problemas.

6 Tese freqüentemente esposada em Ações Civis Públicas propostas pelo Parquet bandeirante.

7 Juarez de Freitas (in "Procedimento Administrativo Federal: reflexões sobre o prazo anulatório e a amplitude do dever de motivação dos atos administrativos". In SUNDFELD, Carlos Ari e outro (coords.). As Leis de Procedimento Administrativo. São Paulo, Malheiros, 2000, pp. 94-108; texto adiante citado extraído da p. 102) afirma que, "se, no plano formal, a nulidade for gravíssima, absoluta e intransponível, então o vício será essencial e insanável, não se deixando jamais convalidar pela ação do tempo, nem havendo o menor sentido, nos limites do sistema, em falar de prazo decadencial para a decretação da nulidade."

8 É o teor da Súmula n. 473: “A Administração pode anular seus próprios atos, quando eivados de vícios que os tornam ilegais, porque deles não se originam direitos; ou revogá-los, por motivo de conveniência e oportunidade, respeitados os direitos adquiridos, e ressalvada, em todos os casos, a apreciação judicial."

9 Essa exegese foi esposada pelo STJ na Súmula n. 119.

10 "Da Convalidação e da Invalidação dos Atos Administrativos", 2 ed., São Paulo, Malheiros, 1996. 
efeitos retroativos), a estabilização desse ato viciado no tempo, cristalizando-se no ordenamento jurídico tal como nele inserto, ocorreria em um lustro (prazo genérico de questionamento judicial dos atos administrativos previsto no Dec. n. 20.910/32, art. $1^{\circ}$ ). Em outra mão, acaso o suposto vício do ato administrativo se aloque em aspecto ou elemento de sua estrutura que não Ihe enseja repetição sem renovação do vício (assim, os casos de vícios localizados na motivação, no conteúdo, na finalidade e na forma, quando sua desobservância original importar na frustração da finalidade para que prevista), a estabilização observaria prazo mais dilargado e como o maior prazo previsto no nosso sistema jurídico seria aquele genérico para as ações pessoais (vinte anos), consoante previsão do antigo $\mathrm{CC}$, art. 177, aplica-o em analogia ${ }^{11}$. Enfim, concebe a presença de atos administrativos viciados absolutamente insanáveis, consubstanciados em hipóteses em que o ato administrativo tem por conteúdo uma prescrição de caráter criminoso, cuja possibilidade de invalidação é imprescritível. $^{12}$

Não poucas respeitáveis penas entendem a possibilidade de continuação da competência administrativa de invalidação dos atos administrativos viciados, ainda uma vez ocorrente a prescrição de seu questionamento na via judicial. Afirmam que se trata de competências distintas e independentes ${ }^{13}$.

Não é bem assim. Tentemos ver porquê.

\section{Desconstruindo para construir:}

A positividade do tema da prescrição - $C F$, art. $37, \S 5^{\circ}-$ Lei $n .9 .784 / 99$ (Lei de Processo Administrativo Federal), art. 54 - inconsistência argumentativa da jurisprudência do STJ sobre prazo vintenário para ações de desapropriação indireta - descabimento do CC, art. 205 (e do antigo similar art. 177) como prazo prescritivo comum para ação de invalidação de ato administrativo - reiteração do prazo qüinqüenal na legislação de direito público - elementos para integração de lacuna normativa.

11 Tal prazo hoje seria de 10 anos, conforme o novel CC, art. 205.

12 Posição semelhante é encontrada em Jacintho de ARRUDA CÂMARA (A Preservação dos Efeitos dos Atos Administrativos Viciados, in Estudos de Direito Administrativo em Homenagem ao Professor Celso Antônio Bandeira de Mello, Tatiana MENDES CUNHA (Org.), São Paulo, Max Limonad, 1996, pp. 70 e ss.). Para uma aprofundada e erudita fundamentação da estabilização dos atos administrativos supostamente viciados pelo decurso do tempo, imprescindível a leitura de Almiro DO COUTO E SILVA. Princípios da Legalidade da Administração Pública e da Segurança Jurídica no Estado de Direito Contemporâneo, in Revista de Direito Público, São Paulo, RT, out-dez/1987, V. 84, ano XX, pp. 46-63.

13 Assim, VLADIMIR DA ROCHA FRANÇA, "Invalidação judicial da Discricionariedade Administrativa no Regime Juridico-administrativo Brasileiro", Rio de Janeiro, Forense, 2000; tese ratificada pelo próprio no painel sobre Atos Administrativos do I Ciclo de Estudos de Direito Público (Natal/RN, 30-31 de agosto de 2001). 
Não vige em nosso sistema jurídico um princípio supranormativo (i.é., metajurídico) da prescritibilidade das ações ${ }^{14}$. Nem também, enquanto princípio, da imprescribitibilidade das ações. O que vigora é um princípio ou regra genérica da prescritibilidade, que, defluído de princípios gerais de direito, notadamente o Princípio da Segurança Jurídica e seu corolário o Princípio da Estabilidade das Relações Jurídicas, encontra maior concreção em nivel legal pela previsão de prazos prescritivos genéricos no Código Civil, art. $205^{15}$ (antes pelo art. 177 no Código de Bevilácqua). Ora, observados certos parâmetros de razoabilidade - de emprego sempre polêmico, seja reconhecido - e certas conformações principiológicas pertinentes a específicos ramos jurídicos, é certo que leis podem excepcionar a regra da prescritibilidade e muito mais certamente a Constituição. Esta, de seu lado, o faz em tom explícito no art. $5^{\circ}, \mathrm{XLII}^{16}$ e XLIV ${ }^{17}$, mas também de forma implícita por confluência, como já dito, de uma principiologia parcialmente incompatível com a prescritibilidade, consoante é o exemplo das ações referentes ao acertamento de seu próprio estado pelas pessoas físicas ${ }^{18}$.

\section{Portanto, nos demais casos, vigora como regra geral a prescritibilidade}

E quanto ao art. $37, \S 5^{\circ}$ da Lei Maior, uma interpretação minimamente objetiva somente consegue dele defluir, no máximo, a imprescritibilidade de ações de ressarcimento em face de danos patrimoniais ou morais provocados por agentes públicos ao Estado. Nesse sentido, isto é, pelo máximo que se poderia retirar sobre eventual imprescritibilidade a partir desse dispositivo, o ressarcimento em favor do Estado diante de danos desse jaez seria judicialmente pleiteável - exigindo-se por certo a comprovação de dano efetivo (não presumido, o qual não decorre ipso facto pela

14 A natureza juspositiva dos princípios jurídicos e as consequências daí assacáveis são expostas por CELSO ANTÔNIO BANDEIRA DE MELLO (Curso de Direito Administrativo, São Paulo, Malheiros, 13 ed., 2001, p. 51), com os admiráveis rigor teórico e elegância de sempre: "Diferentemente dos princípios que regem o mundo físico, no campo do Direito são livremente determinados pelos homens. O legislador acolhe, no sistema normativo que constrói, os princípios que deseja vigorantes. São, bem por isso, mutáveis."

15 "Art. 205. A prescrição ocorre em dez anos, quando a lei não lhe haja fixado prazo menor." 16 "a prática do racismo constitui crime inafiançável e imprescritivel, sujeito à pena de reclusão, nos termos da lei."

17 "constitui crime inafiançável e imprescritível a ação de grupos armados, civis ou militares, contra a ordem constitucional e o Estado Democrático."

18 As açōes sobre o estado civil e outros direitos personalíssimos (como o de autor) constituem açōes declaratórias típicas conforme ensina PONTES DE MIRANDA (Tratado das Ações, Vol. II, Campinas, Bookseller, 1998, pp. 117 e ss.), daí sua imprescritibilidade, visto que "A ação típica de declaração. positiva ou negativa, não prescreve. Se alguma pretensão, ou algumas pretensões, ou todas as pretensões irradiadas da relação jurídica, cuja existência se quer declarada, prescre. veram, não é isso óbice a que se declare a relação jurídica." (Op. cit., p. 156). Mais recentemente, JOÃO BATISTA LOPES, in Ação Declaratória, São Paulo, RT, 3.ed., pp. 98-99, o qual inclusive remete-se a clássico ensinamento de AMORIM FILHO, também mais adiante referido. CÂMARA LEAL (Da Prescrição e da Decadência, Rio de Janeiro, Forense, 2 ed., 1959, pp. 51 e ss.), todavia e com aguçado fundamento, colaciona algumas ações de estado prescritíveis, como a contestatória de paternidade (Op. cit., p. 55). 
simples alegação de presença de vício no ato administrativo, mas requer a comprovação de um prejuízo certo) para que ensejado o deferimento do pedido - , ainda que não mais se possa invalidar o ato administrativo concreto que provocou o revés patrimonial ou moral (bem imaterial estatal que assim possa ser qualificado).

Digo isso, todavia, apenas para atalhar polêmica, visto que em face do que asserido no parágrafo acima, já se conclui que a $\mathrm{CF}$, art. $37, \S 5^{\circ} \mathrm{em}$ hipótese alguma enseja concluir a imprescritibilidade de invalidação de qualquer ato administrativo. Sem embargo, minha opinião - confessadamente minoritária - é de que esse dispositivo constitucional não permite sequer concluir a imprescritibilidade das ações de ressarcimento por supostos danos advindos de atos ilícitos em desfavor do patrimônio público ${ }^{19}$.

19 Em rigor, a imprescritibilidade da invalidação dos atos administrativos não resta imposta pelo dispositivo constitucional em comento. As razões para tanto, expendo mais adiante, mas cumpre desde já registrar nosso admirado acato ao que averbado pelo D. Juiz de Direito BENJAMIM SIMÃO JÚNIOR, ao ensejo de ofício na $7^{\mathrm{a}}$ Vara da Fazenda Pública da Comarca de São Paulo, em sentença lançada nos autos da Ação Civil Pública n. 053.00.015870-7:

"Todos com conhecimento básico de nosso ordenamento jurídico sabem que a regra nele existente não é de imprescritibilidade.

"No entanto não se pode pura e simplesmente repetir tal arraigado conceito em face do que dispõe o inciso XLIV do art. $5^{\circ}$ da Constituição da República.

"(...)

“Nesse processo não se cuida do que dispōe o inciso XLIV do art. $5^{\circ}$ da Constituição da República e sim do que dispõe o $\$ 5^{\circ}$ do art. 37 da mesma Constituição da República.

"Transcrevo no entanto o que dispõe o inciso XLIV do art. $5^{\circ}$ :

'constitui crime inafiançável e imprescritivel a ação de grupos armados, civis ou militares, contra a ordem constitucional e o Estado Democrático'.

"E transcrevo agora o que dispõe o $\$ 5^{\circ}$ do art. 37:

'A lei estabelecerá os prazos de prescrição para ilícitos praticados por qualquer agente, servidor ou não, que causem prejuizos ao erário, ressalvadas as respectivas açōes de ressarcimento."

"Se esse dispositivo estabelece que a lei estabelecerá os prazos de prescrição com relação aos ilicitos e, imediatamente, ressalva 'as respectivas açōes de ressarcimento' é evidente que essa ressalva diz respeito à prescrição das açōes de ressarcimento, mas acontece que isso é a única coisa certa que se pode dizer pois não há absolutamente nada de claro sobre a extensão da ressalva.

"Não se dispõe de elementos para saber se com a ressalva o legislador pretendeu, por exemplo, apenas estabelecer que outra lei haveria de dispor sobre os prazos de prescrição das respectivas ações de ressarcimento, ou se, por exemplo, pretendeu afirmar a desnecessidade de nova lei a respeito dos prazos de prescrição das respectivas açōes de ressarcimento pois para estas continuariam valendo os prazos de prescrição já estabelecidos em nosso ordenamento jurídico, ou mesmo se pretendeu estabelecer a imprescritibilidade das respectivas açōes de ressarcimento.

"Acontece que, pelas razöes que já serão expostas, é escassa a probabilidade de ser verdadeira esta última hipótese.

"Em primeiro lugar é absolutamente necessário não esquecer que em face da natureza da linguagem que usamos são literalmente infinitas as formas de afimar claramente a imprescritibilidade de alguma ação.

"No entanto, comparem-se as redações do inciso XLIV do art. $5^{\circ}$ e do $\$ 5^{\circ}$ do art. 37, ambos da Constituição da República, que torno a transcrever.

"(...) 
Como a prescritibilidade tende a ser a regra geral, pois assim determinava o CC antigo, art. $177^{20}$, bem como o atual CC, art. 205, como também uma compreensão do sistema jurídico com atenção a princípios substanciais como o da Segurança Jurídica e o da Estabilidade das Relações Jurídicas, o entendimento em torno da Lei n. 9.784 , art. 54 não pode referendar a tese de que a invalidação de atos administrativos produzidos supostamente com eiva de má fé configuraria competência perpétua administrativa ou judicial. ${ }^{21}$ Da previsão explícita de prazo específico para a estabi-

"E, se essa fosse a intenção, seria de uma simplicidade única agregar ao $\S 5^{\circ}$ do art. 37. por exemplo, estas três últimas palavras: 'que são imprescritíveis'.

"Em segundo lugar, se é evidente que o legislador, e com mais razão o legislador constituinte, pode alterar completamente o ordenamento jurídico, não é lógico que essa alteração seja feita de forma quase que sorrateira.

"É claro que qualquer técnica jurídica, pode ser alterada pelo legislador.

"Mas, como venho dizendo, NADA autoriza concluir que uma formulação dúbia tenha ali sido colocada com o fim de alterar a situação existente.

"Aqui valho-me das lições do notável CELSO ANTÔNIO BANDEIRA DE MELLO:

'Aduza-se, ainda, que é notório princípio de exegese não presumir que disposições normativas novas infirmam as precedentes, sobreposse quando implicam rompimento com larga tradição legislativa anterior, a menos que isto resulte clara e induvidosamente dos termos do regramento superveniente. Extrair esta consequiência do mero silêncio, então, já é uma liberdade inadmissível.'

“(...)

"E no caso, repito, NADA existe de que possa decorrer a conclusão de alguma 'clara' ou induvidosa' ou 'irresistivelmente clara' intenção de alterar a situação existente quanto à regra da prescritibilidade das ações condenatórias.

"Pelas razōes que acabo de expor, portanto, não sou capaz de concluir que o disposto no $\S 5^{\circ}$ do art. 37 da Constituição da República estabeleça a imprescritibilidade das 'respectivas ações de ressarcimento'.

"Se a regra é de prescritibilidade das ações condenatórias e não se pode afirmar derrogada essa regra, o que se há de decidir é sobre qual, então, seria o prazo de prescrição.

" $E$, conforme sustentaram alguns réus, de fato a regra mais próxima de que se dispõe é claramente estabelecida pela Lei n. 4.717/65, e isso porque se é certo que o Código Civil estabelece regras gerais de prescrição (art. 177) não é menos certo que o âmbito próprio do Código Civil é, aquele clara e elengantemente expresso em seu art. $1^{\circ}$ : 'Este Código regula os direitos e obrigações de ordem privada concernentes às pessoas, aos bens e às suas relações'.

"Celebrado o contrato aos 1990, mais de cinco anos já haviam se passado quando, aos 29 de junho de 2000 , foi ajuizada a ação que iniciou este processo.

"Declaro PRESCRITO o direito pretendido pelo autor..."

20 Assim também no novo Código Civil, em vias de entrar em vigor, art. 205: "A prescriçāo ocorre em dez anos, quando a lei näo lhe haja fixado prazo menor."

21 E aqui o confortável estofo do pensamento de ADÍLSON Abreu DALLARI e SÉRGIO FERRAZ (Processo Administrativo, São Paulo, Malheiros, 2000, p. 166): "Numa interpretação literal, o art. 54 parece querer dizer que, havendo má fé, na prática do ato administrativo, de parte do beneficiário, jamais ocorreria decadência do direito de anular. Essa só seria invocável ou se a má fé fosse imputável ao agente administrativo, ou quando ela inexistisse. Nossa opiniāo a respeito é, contudo, radical: a cláusula final 'salvo comprovada má fé' é inconstitucional, por isso que afrontosa ao princípio da razoabilidade. E não vale, aqui, pretender o primado absoluto do princípio da legalidade. Dúvida não temos em dizer que, pelo correr do tempo, a segurança jurídica coloca entre parênteses o princípio da legalidade." Diferença para a exposição aqui encaminhada 
lização dos atos administrativos viciados favoráveis aos administrados produzidos supostamente sem má fé e do silêncio do dispositivo em referência quanto às hipóteses de atos administrativos viciados desfavoráveis aos administrados com ou sem má fé e favoráveis aos administrados mediante má-fé não é lógica nem sistematicamente lícito concluir que a competência administrativa de invalidação jamais faleceria com o decurso temporal.

Desde já, observemos que a vinculação do tema da decadência ou prescrição à presença ou não de má fé coloca ao órgão competente para invalidação uma situação no mínimo paradoxal. É que um tanto obviamente o acertamento judicial em torno da configuração ou não da prescrição e assim da permanência ou não da competência jurisdicional para invalidação de um ato administrativo supostamente editado mediante má fé é questão logicamente prévia à própria discussão da presença ou não de má-fé como vício procedimental ou material do ato administrativo impugnado. Nessas hipóteses, o mérito abrange pelo menos duas questões, devendo a solução da primeira necessariamente preceder à segunda: primeiro, decide o Juízo se encontra-se ou não prescrito o acesso do autor ao Judiciário em um dado caso concreto; segundo, decide o Juízo, com adstrição ao material probatório coligido nos autos, se constatável ou não a má fé como vício do ato administrativo impugnado.

Ora, as normas ou exegeses que apontam um prazo maior para questionamento de atos administrativos supostamente viciados com má fé produzem uma verdadeira inversão e confusão na solução do mérito, e, levadas em suas últimas consequiências, acabam por impedir a manifestação judicial sobre a configuração ou não da prescrição, porquanto para isto o Juízo deveria invadir a segunda questão de mérito e, portanto, prejudicar aquela questão prévia (configuração ou não da prescrição). Esse paradoxo não oportuniza senão uma solução prática, no exato sentido de utilitarista. No capítulo seguinte, apresento-a.

Do laconismo do art. 54 da Lei n. 9.784/99 não é lógico concluir a perpetuidade da invalidação dos atos administrativos viciados mediante suposta má-fé simplesmente porque o silêncio ou a incompletude normativa, no máximo, autorizaria a aplicação de uma regra geral e sabemos que nem a impreclusividade (termo que Pontes de Miranda acordaria melhor nominar o fenômeno da perpetuação da exercitabilidade de um direito material) nem a imprescritibilidade são a regra geral para o caso que nos ocupa. Portanto, a ilogicidade de seu uso como pretensa ou inadvertida premissa para o raciocínio aqui divergido.

É necessário reler o art. 54 da Lei n. 9.784/99, tarefa que deixo para o próximo tópico.

Em outra mão, nenhuma inconsistência normativa (inconstitucionalidade) comparece no fato de normas, de status legal, determinarem que o questionamento judicial de atos administrativos que importem em desapropriação indireta também

está, entretanto, em que tenciono ofertar ao dispositivo em comento interpretação conforme à constituição. Ainda que, como ver-se-á, adiante, isso implique em um esforço quase hercúleo. 
observe o prazo previsto no Dec. n. 20.910/32, art. $1^{\circ}$ (qüinqüenal). A implicitude, segundo conhecimento já tornado truísmo, não é um mecanismo menor de externação da norma ${ }^{22}$, donde a fragilidade de um argumento que tome como premissa a impossibilidade da norma legal prever implicitamente um usucapião extraordinário em favor do Estado. ${ }^{23}$

E quanto à aplicação analógica dos prazos previstos no Código Civil para regramento da estabilização dos atos administrativos viciados, essa solução encontra hipóteses bem mais restritas do que geralmente advogado na doutrina. De primeiro, já assomava em desprestígio de uma aplicação irrestrita ou ampla do prazo vintenário - consoante defende difundida doutrina ${ }^{24}$, acompanhada de manifestações jurisprudenciais - a percepção de que o regramento contido no antigo $\mathrm{CC}$, art. 177 é próprio de uma sociedade agrária e de parcos recursos tecnológicos, de um mundo de difícil e demorada comunicação: meados da segunda década do século passado. Era e é um tanto incontornável daí asserir que a noção de tempo dos nossos antepassados de primórdios do Séc. XX dista em muito daquela necessária e pertinente aos tempos atuais, de uma sociedade urbanizada e de um mundo de comunicação facilitada, de informações televisionadas em tempo real. Perante esse contexto, a aplicação ampla da prescrição vintenária para estabilização dos atos administrativos significava, quando menos, uma solução anacrônica - e ocioso, aqui, citar ampla doutrina que propugna ao intérprete da lei o dever de contextualizá-la diante do seu entorno

22 CELSO ANTÔNIO BANDEIRA DE MELLO (Curso..., 13 ed., pp. 51-52; negrito acrescido) expõe em termos irretorquíveis: "Ao ser, pouco a pouco, delineado um dado sistema, pode o Legislativo fixar inconscientemente un conjunto de princípios que, deseje ou não, estarão informando o sistema, desde que as normas postas traduzam sua acolhida. Ao jurista interessam, portanto, os princípios consagrados, haja ou não o le gislador pretendido conscientemente instaurá-los. Estes cânones, entretanto, estão sempre à disposição da autoridade legislativa, pelo quêe podem ser, a qualquer tempo, modificados, derrogados, seja pela substituição dos princípios básicos, seja pela alteração deles nos vários institutos particulares de uma dada disciplina.." Assim também em ROQUE ANTÔNIO CARRAZZA (Curso de Direito Constitucional Tributário, São Paulo, Malheiros, 5 ed., 1993, p. 27): "Não importa se o princípio é implícito ou explícito, mas, si, se existe ou não existe. Se existe. o jurista, com o instrumental téórico que a Ciência do Direito coloca à sua disposiçăo, tem condiçōes de discerni-lo. De ressaltar, com Souto Maior Borges, que o princípio explicito não é necessariamente mais importante que o princípio implícito. Tudo vai depender do âmbito de abrangência de um e de outro e, não, do fato de um estar melhor ou pior desvendado no texto jurídico. Aliás, as normas jurídicas nāo trazem sequer expressa sua condiçẫo de princípios ou de regras. É o jurista que, ao debruçar-se sobre elas, as identifica e as hierarquiza."

23 Outro e talvez melhor nível de argumentação em favor da tese de afastamento do prazo qüinquienal para os casos de desapropriação indireta seria encontrado a partir do princípio da isonomia, entretanto, essa linha argumentativa teria necessariamente de se defrontar com a aceitação, ainda pouco polemizada, da instituição de posiçōes jurídicas, sobretudo processuais, de vantagem do Estado diante do administrado.

24 ELIVAL DA SILVA RAMOS (A Valorização do Processo Administrativo. O poder regulamentar e a invalidação dos atos administrativos. In SUNDFELD, Carlos Ari e outro (coords.). As Leis de Procedimento Administrativo. São Paulo, Malheiros, 2000, pp. 75-93, especificamente à p. 90 , nota 35$)$. 
social... A propósito, outro não é o mandamento da Lei de Introdução ao Código Civil, art. $5^{\circ} .{ }^{25}$

Antes de mais nada, notemos a presença de regra hermenêutica incontornável para o uso da analogia como método integrativo, a saber: na procura da norma a ser aplicada como recurso analógico para integração da lacuna identificada, deve o exegeta principiar sua busca nos campos jurídicos que guardem maior proximidade principiológica com aquele setor do ordenamento em que percebida a lacuna. ${ }^{26}$

Em atenção a isso, a pesquisa por normas que possam servir ao procedimento analógico, in casu, deve iniciar-se pelas disposições normativas que compõem o direito público, notadamente aquelas que integram normações materialmente mais próximas do setor em que sentida a lacuna. Nesse diapasão, bem antes do antigo art. 177 do CC e mesmo do atual art. 205 do Código em vigor, devem avultar aos olhos do intérprete as disposições contidas no Código Civil (Lei n. 3.071, de $1^{\circ}$ de janeiro de 1916), art. 178, $\S 10, \mathrm{VI}^{27}$, nisto confirmado e ampliado pelo Dec. 20.910, de 6 de janeiro de 1932, art. $1^{\text {o28 }}$ e pelo Decreto-lei n. 4.952, de 19 de agosto de 1942,

25 Apenas a título de ilustração, valem, por todos, esse excerto de CAIO TÁCITO, que, por sempre luminosa pena, escreve em termos particularmente oportunos: "A chamada interpretação sociológica desenvolve o conceito social da lei, para extrair a filiação da norma jurídica com as condições sociais que motivam, em cada época, a elaboração e a evoluçāo do Direito. A sua expressão, no direito norte-americano, através da sociological jurisprudence (POUND, LEWILLYN. HOLMES), levou a interpretação constitucional aos extremos salutares da construção (construction), permitindo o lento e constante ajustamento do texto da Carta de Filadélfia, elaborada, como já se disse, à luz de candeeiros, para uma jovem naçāo agrícola de três milhöes de habitantes, de modo a permitir a sua vigência no século da eletricidade, à mais poderosa organização industrial do mundo contemporâneo. A interpretação da norma jurídica não se poderá fazer, em suma, senão em consonância com a sua causalidade social, ou, na terminologia atual do direito brasileiro, segundo os 'fins sociais a que ela se dirige e as exigências do bem comum' (art. $5^{\circ}$ da Lei de Introduçāo ao Código Civil). A tal método se subordina a interpretação da norma administrativa (...)"; "Interpretação da Norma Administrativa. Métodos. Analogia. Eqüidade", in Temas de Direito Público, I, Rio de Janeiro, Renovar, 1997, p. 503; sublinhado acrescido)

26 Na lição imorredoura de CARLOS MAXIMILIANO (Hermenêutica e Aplicação do Direito, Rio de Janeiro, Forense, 18 cd., 2000, p. 212; sublinhado acrescido): "(...) cumpre também fazer prevalecer, quanto à analogia, o preceito clássico, impreterivel: não se aplica uma norma jurídica senão à ordem de coisas para a qual foi estabelecida. Não é lícito pôr de lado a natureza da lei, nem o ramo do Direito a que pertence a regra tomada por base no processo analógico. Quantas vezes se não verifica o nenhum cabimento do emprego de um preceito fixado para o comércio, $e$ transplantado afoitamente para os domínios da legislação civil, ou da criminal, possibilidade esta mais duvidosa ainda! Decide-se com presumivel acerto desde que se procurem e confrontem casos análogos subordinados a leis análogas."

27 "Art. 178. Prescreve: (...) § 10. Em 5 (cinco) anos: (...) VI - As dívidas passivas da Uniāo, dos Estados e dos Municípios, e bem assim toda que qualquer ação contra a Fazenda federal, estadual ou municipal; devendo o prazo da prescrição correr da data do ato ou fato do qual se originar a mesma açāo."

28 "As dividas passivas da União, dos Estados e dos Municípios, bem assim todo e qualquer direito ou ação contra a Fazenda Federal, estadual ou municipal, seja qual fôr a sua natureza, prescrevem en cinco anos contados da data do ato ou fato do qual se originarem." Mediante este diploma, extrai-se nítida intençāo em definir o prazo de um lustro como interregno temporal máximo para a 
art. $2^{\text {o29; }}$ a L. 4.717 , de 29 de junho de 1965 , art. $21^{30}$. Em todas elas, o prazo prescritivo em indagação é de cinco anos. ${ }^{31}$ Assim também quanto aos lançamentos tributários - consoante depreende-se do Código Tributário Nacional (Lei n. 5.172, de 25.10 .1966 ), arts. $168^{32}$ e $174^{33}$. Regrando o prazo decadencial para punição em exercício de poder de polícia administrativa federal, a Lei n. 9.873, de 23 de novembro de 1999 , art. $1^{\circ}$ prevê o mesmo prazo (cinco anos) ${ }^{34}$.

\section{Para uma tentativa de sistematização das soluções ofertáveis ao problema em foco}

a) A estabilização dos atos administrativos viciados se dá com a operação da prescrição: primeiro fundamento

Primeiramente, firmemos que a estabilização dos atos administrativos viciados pelo decurso temporal observa como marco último o prazo previsto de acesso ao

prescrição à épocal, consoante seu art. 10, que determinava: " $O$ disposto nos artigos anteriores nāo altera as prescriçōes de menor prazo, constantes das lcis e regulamentos as quais ficam subordinadas às mesmas regras." Obviamente, tal disposição não vincula o legislador hodierno, apenas sublinha a clareza com que o sistema normativo d'então regulou o tema.

29 "O Decreto n" 20.910, de 6 de janeiro de 1932, que regula a prescrição qüinqüenal, abrange as dívidas passivas das autarquias, ou entidades e órgãos paraestatais, criados por lei e mantidos mediante impostos, taxas ou quaisquer contribuiçöes, exigidas em virtude de lei federal, estadual ou municipal, bem como a todo e qualquer direito e ação contra os mesmos. "

30 "A ação prevista nesta lei prescreve em 5 (cinco) anos."

31 Desta forma, não pecasse já pela ausência de seus pressupostos constitucionais (CF, art. 62), a Medida provisória n. 2.102-28, de 23 de fevereiro de 2001 , pecaria pela desnecessária repetição ao determinar inclusão de novo art. $1^{\circ}$-C na Lei n. $9.494 / 97$ com seguinte texto: "Prescreverá em cinco anos o direito de obter indenização dos danos causados por agentes de pessoas jurídicas de direito público e de pessoas jurídicas de direito privado prestadoras de seniços públicos." Seja ainda permitida a digressão: aos vícios referidos, seja acrescido outro, de conotações perversas tāo ou mais piores que a sublinhada inconstitucionalidade. É que a Medida provisória em comento consiste verdadeira deturpação dos fins para que instituída a competência presidencial do art. 62 , à medida que revela o uso do poder normativo pela Presidência da República para instituir privilégios processuais para a Administração quando levada a Juízo. Referido desvio de poder estampa-se ainda mais quando observado que o texto dessa Medida provisória foi elaborado pelo Advogado Geral da União, provavelmente furibundo com os "empecilhos" que a legalidade estava impondo ao ofício seu e de seus subordinados de defender a União Federal.

32 "Art. 168. O direito de pleitear a restituição extingue-se com o decurso do prazo de 5 (cinco) anos, contados...".

33 "Art. 174. A ação para a cobrança do crédito tributário prescreve em 5 (cinco) anos, contados da data da sua constituição definitiva."

34 "Art. $1^{\circ}$. Prescreve em cinco anos a ação puniriva da Administração Pública Federal, direta e indireta, no exercício do poder de polícia, objetivando apurar infração à legislação em vigor, contados da data da prática do ato ou, no caso de infração permanente ou continuada, do dia em que tiver cessado." 
Judiciário para o pleito de invalidação do ato. Em palavras mais diretas: uma vez não mais possivel acorrer ao Judiciário para invalidar um ato administrativo porque transcurso o prazo último instituído para tanto, não mais persiste a competência estatal para em sede administrativa, de oficio ou por provocação, procedê-lo. ${ }^{35}$

Essa conclusão escora-se em duas ordens de fundamento: uma, de natureza sintática; outra, face à repartição de funções fundamentais entre os Poderes vigente em nosso Texto Constitucional. Principiemos por esse segundo fundamento.

A positivação do mecanismo da separação de poderes entre nós deu-se, desde longa tradição, incumbindo-se o Judiciário do exercício do papel de máximo, último intérprete e aplicador do ordenamento jurídico. criando, por assim dizer, uma hierarquia entre os órgãos fundamentais do Estado nos seguintes termos: quanto ao encontro e criação de significações normativas a partir do ordenamento jurídico, mormente dos Textos Constitucional e Legal, o Judiciário profere a manifestação prevalecente quando instado a tanto. Nessa assertiva, nada mais se faz que esclarecer o que inserto no cânone da inafastabilidade da Jurisdição (CF, art. $\left.5^{\circ}, \mathrm{XXXV}\right)$ e da coisa julgada $\left(\mathrm{CF}\right.$, art. $\left.5^{\circ}, \mathrm{XXXVI}\right){ }^{36}$

Nosso Ordenamento Constitucional, diferentemente do Ordenamento francês, entre outros, não instituiu a chamada Jurisdição Administrativa, mediante a qual os atos administrativos submetem-se ao crivo de validade exclusivamente no âmbito da organização administrativa, o que ensejaria à Administração a posição, nesses estritos casos (controle de validade dos atos administrativos em sentido amplo), de órgão hierarquicamente qualificado para interpretar e aplicar o ordenamento jurídico.

Ao contrário, vigendo entre nós a unidade da Jurisdição, essa função não é repartida entre os poderes estatais, restando todos submetidos ao último crivo de juridicidade de seus atos pelo Poder Judiciário, nem que seja apenas para que este, sindicando dado ato ou fato jurídico, cinja-se a, averiguando requisitos extrínsecos de validade, controle o mérito cabível à decisão d'outro poder apenas (e assim deve ser) em face da verificação de irrazoabilidade patente ou desvio de poder (desse modo, respeita o Judiciário o campo decisório potencial em que se exerce a função d'outro poder).

Perante nosso Ordenamento Constitucional, cabendo ao Judiciário a função de intérprete e aplicador do direito hierarquicamente qualificado diante do Estado-administrador ${ }^{37}$, seria sistematicamente incoerente supor poder a Administração per-

35 Observemos que o prazo de acesso ao Judiciário para invalidação dos atos administrativos pode encontrar diferentes marcos a depender da via processual manejável. Assim, o prazo do mandado de segurança (120 dias) e o prazo genérico das ações ordinárias para esse fim (5 anos). Em face disso, quando penso em transcurso do prazo de acesso ao Judiciário como marco temporal de estabilização dos atos administrativos, a referência certamente é feita ao prazo maior.

36 Pelas palavras de CÂNDIDO RANGEL DINAMARCO ("Litisconsórcio Necessário - Controle Jurisdicional do Ato Administrativo", in Revista Forense, Rio de Janeiro, Forense, V. 333, p. 187: sublinhado acrescido): "O Judiciário é o guarda da Constituição, com a última palavra sobre a compatibilidade constitucional das le is elaboradas nas casas legislativas, e só o que ele pronuncia tem 'final enforcing power' inclusive sobre atos de Governo."

37 Nas páginas célcbres dos "Princípios Gerais de Direito Constitucional dos Estados Unidos da 
manecer no gozo da competência invalidante de seus atos administrativos, quando o Judiciário já não mais o pudesse; é dizer, quando o órgão máximo da aplicação do direito em nosso sistema jurídico não mais tivesse a competência para constituir a invalidade de um ato administrativo supostamente viciado. Em outras palavras, se o órgão mais qualificado para produzir o juízo de validade quanto a quaisquer atos jurídicos, inclusive os atos administrativos, não mais o pode fazer diante de um específico ato administrativo porque operada a prescrição (ou decadência, para Amorim Filho ${ }^{38}$ ), impõe-se concluir que muito menos o pode um outro órgão menos

América" (Trad. Alcidez Cruz, São Paulo, RT, 2 ed., 1982, pp. 165-166; sublinhado acrescido), encontra-se essa secular lição de THOMAS COOLEY, voltada sobre um sistema de jurisdição una como o nosso: “...o poder judiciário é a autoridade suprema na interpretação da Constituição e na interpretação das leis, e as suas interpretaçōes devem ser acceitas e observadas pelos outros dcpartamentos. Isto é a que resulta da natureza da sua jurisdição; as questōes de interpretação surgidas nas controvérsias legaes e resolvidas pelos tribunaes, uma vez resolvidas, têm estes autoridade para fazer effectivas as suas resoluçōes. Suas sentenças tornam-se leis do país nos pontos decididos por elles, e a desobediencia ou desattenção que sofram, tanto de um simples particular como de um funccionario publico, produzirá nova controvérsia que em última instancia virá a ser decidida da mesma maneira pelo poder judiciário." E o verbo fulgente de SEABRA FAGUNDES ("O Controle dos Atos Administrativos pelo Poder Judiciário, Rio de Janeiro, Freitas Bastos, 1941, pp. 87-88; sublinhado acrescido) encarece a importância dessa preeminência do Judiciário sobre a Administração sobretudo em regimes presidencialistas como o nosso: "Nos paises de regime presidencial, como o nosso, ficando o Executivo, praticamente, acima das intervençōes do Parlamento (...). cresce de importancia a interferencia jurisdicional no exame da atividade administrativa. Torna-se indispensavel dar-lhe estrutura e desenvolvimento correspondentes ao seu relevante papel no vinculamento da função administrativa á ordem juridica. Na realidade, é só por ele que se confina, dentro da Constituição e das leis, a exercicio do Poder Executivo, que colocado acima do contrôle eficiente do Parlamento, só na atuação do Poder Judiciario pôde encontrar limitação eficaz do ponto de vista jurídico."

38 Talvez a melhor sistematização sobre prescrição e decadência tenha sido feita em brilhante estudo de Agnelo AMORIM FILHO, denominado "Critério científico para Distinguir a Prescriçāo da Decadência e para Identificar as Ações Imprescritiveis" (in Revista Forense, n. 193, pp. 30-49. Rio de Janeiro, Forense, 1961). Nele, o Professor da Faculdade de Direito da Universidade da Paraíba, primeiramente criticando a distinção entre os dois institutos com base nos seus efeitos (extinção da relação material ou formal, cf. p. 31 de seu trabalho) e, assim, criticando CÂMARA LEAL pelo empirismo de seu critério distintivo ("...o autor não fixou, em bases científicas, uma nonna para identificar aquelas situaçōes em que o direito nasce, ou não, concomitantemente com a ação. pois é este seu ponto de parfida para distinção entre os dois institutos.", p. 31), averbou que a apartação deve ser feita com base na categoria dos direitos tutelados mediante açăo. Assim, os prazos de judiciabilidade dos "direitos a uma prestą̧ão (direitos reais e pessoais)" são prescritivos, enquanto aqueles correlacionados aos direitos potestativos ("aquêles podêres que a lei confere a deterninadas pessoas de influirem, com uma declaração de vontade, sôbre situações juridicas de outras, sem o concurso da vontade destas. ", cf. p. 32 do mesmo trabalho), decadenciais. (Daí o autor concluir: 1) "tôdas as açōes condenatórias (e sòmente elas) estāo sujeitas a prescrição" estão sujeitas a prescrição" (p. 38);2) "os tínicos direitos para os quais podem ser fixados prazos de decadência são os direitos potestativos. E. assim. as únicas açōes ligadas ao instituto de decadência são as ações constitutivas que têm prazo especial de exercício fixado em lei." (p. 40): 3) "são perpétuas (ou imprescritiveis) tôdas as açōes declaratórias, e também aquelas açōes constitutivas para as quais a lei nôo fixa prazo especial de exercício." (p. 47). 
qualificado (a Administração Pública, no que atina com a função em causa), diante do próprio ordenamento jurídico tal qual positivado entre nós, para proceder ao juízo de validade face ao direito positivo.

Repisemos, pois: transcurso o prazo de acesso ao Judiciário para invalidação de um ato administrativo supostamente viciado, sua estabilização por decurso temporal estará operada, pois à Administração não mais resta a competência invalidante. ${ }^{39}$ Em síntese: é o prazo de acesso ao Judiciário que regra o marco temporal de estabilização dos atos administrativos supostamente viciados.

b) A estabilização dos atos administrativos viciados se dá com a operação da prescrição: o segundo argumento

Cabe, agora, apresentar a segunda ordem de fundamento para a conclusão de que o prazo de acesso ao Judiciário para invalidação dos atos administrativos supostamente viciados constitui o marco temporal da estabilização desses atos jurídicos, independentemente do manejo da convalidação. Trata-se este, como antes dito, de um fundamento defluído da organização sintática das normas jurídicas. Vejamo-lo.

As normas jurídicas, unidades de significação prescritiva de condutas qualificadas pela institucionalização da sanção em face de seu descumprimento, estruturam-se, como ensinam Kelsen ${ }^{40}$ e Lourival Vilanova ${ }^{41}$, no plano de suas formas lógicas, como composições bimembres, onde, por sua vez, cada membro similarmente integra-se por duas porções.

A primeira decomposição da estrutura bimembre das normas jurídicas é identificada como as subestruturas "norma primária" e "norma secundária". Esta, prevê a relação jurídica sancionadora que haverá vez na hipótese de descumprimento do dever jurídico previsto na norma primária. Notemos, pois, novamente com Kelsen e Lourival Vilanova, que a norma secundária justamente peculiariza a juridicidade da norma jurídica: sem a norma secundária, prescritiva da relação processual (institucional) de aplicação da sanção, o dever e o direito material ou processual previstos na norma primária não apresentam nenhum atributo especial que permita distinguilos de outros deveres e direitos derivados de normas pertencentes a outros subsistemas deônticos (Moral, Religião, Bons Costumes etc.). Di-lo, irretorquivelmente, Lourival Vilanova:

"Se de uma norma jurídica suprime-se a norma secundária sancionadora da norma primária, fica a norma primária desprovida de juridicidade. Poderá permanecer como norma do uso, do costume, como norma social, desjuridicizando-se assim." 42

39 Em igual sentido, CELSO ANTÔNIO BANDEIRA DE MELLO (Curso..., 13 ed., p. 208).

40 Teoria Geral das Normas, Trad. de José Florentino Duarte. Porto Alegre, Sergio Antonio Fabris editor, 1986, pp. 181-183.

41 Causalidade e Relação no Direito, pp. 112-114.

42 Causalidade e Relação no Direito, São Paulo, Saraiva, 2 ed., 1989, p. 113. 
Podemos descrevê-las, em linguagem parcialmente formal, do seguinte modo:

Dado um fato $F$, deve-ser uma relação jurídica $R$, onde a $X$ caberá o dever de executar em favor de $Y$ uma dada prestação $P$; caso ocorrido $F$, surgida a relação $R$ e descumprida a prestação $P$, deverá-ser uma relação processual $R P$, onde $Y$ terá direito ao acesso ao Judiciário (órgão sancionador último) para pedir a observância forçada da prestação $P$ por $X$ ou do sucedâneo jurídico dessa prestação (geralmente, ressarcimento).

Nada obstante inapelavelmente sintéticas, essas considerações já permitem perceber que, acaso impedida a aplicação da norma secundária (que prevê a relação jurídica processual com o Judiciário para aplicação da sanção pelo descumprimento do dever contido na norma primária), a parcela restante da norma jurídica (sua porção primária) não mais é favorecida por um mecanismo de aplicação forçada institucional e. portanto, deixa de ser um dever jurídico. Assim descaracterizada enquanto norma jurídica a porção primária pela impossibilidade (p. ex., devido à prescrição) da operação da norma secundária, deflui que aquilo antes produzido com desobservância de uma dada norma primária, já agora não mais encontra nenhuma norma concreta com que se incompatibilize (a norma concreta que dava fundamento jurídico à possibilidade de questionamento do descumprimento de um dever inscrito na norma primária não subsiste à inoperância - extinção face à prescrição - de sua correspectiva norma secundária).

Ora, se esse "aquilo antes produzido com desobservância de uma norna primária" se tratar de um ato administrativo viciado, a descaracterização da juridicidade dessa norma primária pela extinção da sua correlata secundária importará na estabilização do ato administrativo supostamente viciado tal como produzido. Daí, afirmar que o prazo de acesso ao Judiciário (decadencial ou prescritivo, consoante respectivamente nos atermos ou não à sistematização de Amorim Filho) consubstancia o prazo de estabilização dos atos administrativos viciados, prevalecendo sobre eventuais distintos prazos previstos para a invalidação administrativa dos atos administrativos supostamente viciados.

c) Competência legislativa da Uniäo Federal e correlą̧ões com as competências legislativas do demais entes federativos

Como, entre nós, o regramento do marco temporal de acessibilidade ao Judiciário, tema de direito processual, insere-se na competência legislativa da União Federal (CF, art. 22, I), serão normas federais que regrarão o tema para todas as esferas governamentais. Disso resulta que, se uma lei de ente da federação distinto da União Federal prever prazo a maior que aquele abstratamente prescrito pela legislação federal para invalidação administrativa de seus atos administrativos supostamente viciados, a competência administrativa invalidante somente permanecerá enquanto não transcorrido o prazo previsto para prescrição (acesso ao Judiciário temporalmente definido pela Lei Federal).

Em outra mão, a legislação de outros entes federativos distintos da União Federal pode prever prazo menor para estabilização dos seus atos administrativos perante a própria Administração. Nesse caso, a competência legislativa dos demais entes 
federativos prevalece por cingir-se ao regramento da atuação da Administração pública dentro de seu próprio âmbito sem colidir com o exercício da função fundamental posta ao Judiciário.

\section{d) Os prazos}

O prazo geral é o qüinqüenal, consoante defluído de reiteradas manifestações normativas. De fato, desde o antigo Código Civil (Lei n. 3.071, de $1^{\circ}$ de janeiro de 1916), art. $178, \S 10, \mathrm{VI}^{43}$, nisto confirmado e ampliado pelo Dec. 20.910 , de 6 de janeiro de 1932, art. $1^{\text {ot4 }}$ e pelo Decreto-lei n. 4.952 , de 19 de agosto de 1942, art. $2^{\text {o45 }}$; a L. 4.717 , de 29 de junho de 1965 , art. $21^{46}$ o prazo prescritivo em indagação é de cinco anos. ${ }^{47}$ Assim também quanto aos lançamentos tributários - consoante depreende-se do Código Tributário Nacional (Lei n. 5.172, de 25.10.1966), arts. $168^{48}$ e $174^{49}$. Regrando o prazo decadencial para punição em exercício de poder de

43 "Art. 178. Prescreve: (...) \$ 10. Em 5 (cinco) anos: (...) VI - As dívidas passivas da Uniāo, dos Estados e dos Municípios, e bem assim toda que qualquer ação contra a Fazenda federal. estadual ou municipal: devendo o prazo da prescrição correr da data do ato ou fato do qual se originar a mesma ação."

44 "As dívidas passivas da União, dos Estados e dos Municípios, bem assim todo e qualquer direito ou ação contra a Fazenda Federal, estadual ou municipal, seja qual fôr a sua natureza, prescrevem em cinco anos contados da data do ato ou fato do qual se originarem." Mediante este diploma, extrai-se nítida intenção $\mathrm{cm}$ definir o prazo de um lustro como interregno temporal máximo para a prescrição à época, consoante seu art. 10, que determinava: " $O$ disposto nos artigos anteriores não altera as prescrições de menor prazo, constantes das leis e regulamentos as quais ficam subordinadas às mesmas regras. " Obviamente, tal disposição não vincula o legislador hodierno, apenas sublinha a clareza com que o sistema normativo d'então regulou o tema.

45 "O Decreto $n^{\circ} 20.910$, de 6 de janeiro de 1932, que regula a prescrição qüinqüenal, abrange as dividas passivas das autarquias, ou entidades e órgãos paraestatais, criados por lei e mantidos mediante impostos, taxas ou quaisquer contribuiçōes, exigidas em virtude de lei federal, estadual ou municipal, bem como a todo e qualquer direito e ação contra os mesmos."

46 "A ação prevista nesta lei prescrev'e em 5 (cinco) anos."

47 Desta forma, não pecasse já pela ausência de seus pressupostos constitucionais (CF, art. 62), a Medida provisória n. 2.102-28, de 23 de fevereiro de 2001 , pecaria pela desnecessária repetição ao determinar inclusão de novo art. $1^{\circ}-\mathrm{C}$ na Lei n. 9.494/97 com seguinte texto: "Prescreverá em cinco anos o direito de obter indenização dos danos causados por agentes de pessoas jurídicas de direito público e de pessoas jurídicas de direito privado prestadoras de serviços públicos." Seja ainda permitida a digressão: aos vícios referidos, seja acrescido outro, de conotações perversas tão ou mais piores que a sublinhada inconstitucionalidade. É que a Medida provisória em comento consiste verdadeira deturpação dos fins para que instituída a competência presidencial do art. 62, à medida que revela o uso do poder normativo pela Presidência da República para instituir privilégios processuais para a Administração quando levada a Juízo. Referido desvio de poder estampa-se ainda mais quando observado que o texto dessa Medida provisória foi elaborado pelo Advogado Geral da União, provavelmente furibundo com os "empecilhos" que a legalidade estava impondo ao ofício seu e de seus subordinados de defender a União Federal.

48 "Art. 168. O direito de pleitear a restituiçāo extingue-se com o decurso do prazo de 5 (cinco) anos. contados...".

49 "Art. 174. A ação para a cobrança do crédito tributário prescreve em 5 (cinco) anos, contados 
polícia administrativa federal, a Lei n. 9.873 , de 23 de novembro de 1999 , art. $1^{\circ}$ prevê o mesmo prazo (cinco anos) $)^{50} .5$

A Lei n. 9.784/92, art. 54 prevê similarmente o prazo qüinqüenal para a invalidação administrativa de atos administrativos viciados favoráveis aos administrados produzidos em boa fé. Do seu texto, fica a nítida impressão de dever-se encontrar prazo maior para as hipóteses, favoráveis ou desfavoráveis, de atos administrativos eivados de má fé (intencionalidade e consciência de praticar o ilícito). Todavia não indica o dispositivo em consideração que prazo seria esse, impondo que o exegeta forceje por encontrar no sistema o regramento cabível.

Antes de continuar, uma questão merece esclarecimento: por que o disposto pelo art. 54, da Lei n. 9.784/99 teria relevância normativa (não por expediente integrativo, mas por direta incidência) para o regramento da estabilização dos atos administrativos supostamente viciados produzidos por entes federativos distintos da União Federal?

O esclarecimento se faz com remissão ao que constatado anteriormente: é normação federal aquela competente para dispor sobre o prazo de acesso ao Judiciário (tema de direito processual) para o fito de invalidação de atos administrativos supostamente viciados, daí a relevância do disposto pelo art. 54 da Lei n. 9.784/99 sobre o tema aqui investigado. Resta, entretanto, ainda um detalhe: o dispositivo legal em consideração regula o prazo de invalidação pela própria Administração de atos administrativos viciados, regra, pois, o período de vigência da possibilidade do exercício da autotutela pela Administração Federal, donde a pergunta: o que permitiria estender essa normação ao prazo de acesso ao Judiciário para invalidação dos atos administrativos?

A resposta está no fato de que, sendo o legislador federal o único competente para regrar o prazo de acesso ao Judiciário (prescrição ou decadência, consoante a linha doutrinária adotada), a externação - ainda que incompleta - em disposição legal federal prescritiva de um prazo maior que o comum (qüinqüenal) para invalidação de certos atos administrativos implicitamente aponta que também o prazo de acesso ao Judiciário (o qual não pode ser inenor que o previsto para exercício da autotutela) seja expandido em mesma medida. Isso, notemos, é possível concluir porque as determinações do legislador federal sobre o tema podem, dada sua competência para legislar acerca de processo civil (CF, art. 22, I), repercutir na normação do prazo de acesso ao Judiciário para o pleito de invalidação de atos administrativos. ${ }^{52}$

da data da sua constituição definitiva."

50 "Art. $1^{\circ}$. Prescreve em cinco anos a ação punitiva da Administração Pública Federal, direta e indireta, no exercício do poder de polícia, objetivando apurar infração à legislação em vigor, contados da data da prática do ato ou, no caso de infração permanente ou continuada, do dia em que tiver cessado."

5! Com outro tema em foco - prazo prescritivo para interposição de ação pela Administração contra administrado - CELSO ANTÔNIO BANDEIRA DE MELLO (Curso..., 13 ed., pp. 210-211) e sua singular agudez também conclui que, ainda presente uma lacuna específica, tal seria mesmo o quiinquienal em face de sua reiterada referência em várias normas especificamente voltadas ao Direito Público.

52 Com efeito, proviesse de outro ente federativo uma disposiçāo semelhante à do art. 54 da Lei n. 9.784/99 e nenhuma consequiência ensejaria ao regramento da vigência do direito de acesso ao 
Feito os esclarecimentos devidos, voltemos à interpretação do art. 54 da Lei n. 9.784/99 quanto ao prazo para invalidação dos atos administrativos viciados supostamente por ma fé. Não sendo o caso de imprescritibilidade (pois, consoante visto, a regra geral é a da prescritibilidade), podem ser ofertadas duas soluções. Uma, seria reler o art. 54 em questão e concluir que, em caso de má fé, o prazo quiinqüenal seria contado da ciência desse vício pelos legitimados à proposição de pleitos judiciais de invalidação. Essa solução, se tem a vantagem de fundar-se no próprio dispositivo sob interpretação, oferece a desvantagem de dificultar o encontro do dies a quo para contagem do prazo prescritivo, porquanto sempre será de tormentosa prova a verificação da data em que o autor de uma demanda tomou conhecimento da suposta má fé para dai contar-se o lustro prescritivo.

Outra solução mais direta e por isso mesmo preferível, nada obstante socorrer-se de outra disposição para integração analógica (mas isto, certamente, é um mal menor ou mesmo mal nenhum), encontra-se na aplicação do prazo prescritivo previsto para o questionamento dos atos administrativos supostamente viciados pela improbidade administrativa, consoante a previsão da Lei n. 8.429/92, art. 23 , I. ${ }^{53}$ Esta solução ganha em satisfatoriedade perante o sistema positivo quando notado que a má fé, tirante exageros literais do texto da Lei $n$. 8.429/92, é característica intrinseca, ao menos por um viés semântico razoável e historicamente trilhado, à noção de "improbidade". Temos aí, portanto, uma disposição normativa regrando o tema da prescrição, a qual subjaz um juízo político, juridicamente positivado, sobre o prazo idôneo para acesso ao Judiciário em torno de hipótese em que supostamente presente a má fé. Donde a idoneidade normativa e integrativa do art. 23, I para reger a

Judiciário para invalidação dos atos administrativos viciados. Aliás, exemplo concreto disso, temos na Lei Paulista de Processo Administrativo, Lei n. 10.177, de 30 de dezembro de 1998, art. 10, I, que, prevendo um prazo de 10 anos para exercício da competência administrativa de invalidação dos atos administrativos estaduais supostamente viciados, não enseja sobrevida à essa competência uma vez transcorrido o prazo de acesso ao Judiciário para a invalidação desses mesmos atos.

53 Após esse período, olhando para o alto, talvez encontrasse o sobrolho repreensivo de PONTES DE MIRANDA (Tratado de Direito Privado, Rio de Janeiro, Borsoi, 1955, Tomo VI, p. 126): “As regras jurídicas sôbre prescrição hão de ser interpretadas estritamente, repelindo-se a própria interpretação analógica." Não enfrento, aqui, os fundamentos de tal assertiva peremptória e mesmo compreendo a gravidade e os riscos prováveis se os operadores do sistema jurídico saíssem por aí afora a construir prazos prescritivos por analogia. Contudo, a solução para a ausência de prazo específico seria a utilização do prazo geral, consoante a obviedade de que, na ausência de norma especial, aplica-se a geral. Daí provavelmente ter PONTES DE MIRANDA sentido-se confortável em fazer sua proclamação, reparando (aqui, conjeturo) mais de perto o sub-sistema jurídico composto pelo Código Civil. Entretanto, por várias razões (supra expostas) tenho que o prazo prescritivo comum do Código Civil não pode ser usado no caso, ao menos como prazo prescritivo comum. D'outro bordo, o que seria o prazo prescritivo comum no direito público - cinco anos - justamente não pode ser empregado aqui, visto estar em pauta hipótese (ato administrativo supostamente viciado com má fé) que, não somente o art. 54 da Lei n. 9.784/99, mas também a boa fé administrativa, a razoabilidade e a proporcionalidade jurídicas indicam requerer prazo prescritivo especifico maior. Como sair dessa verdadeira sinuca de bico: não encontro outra solução substancialmente $-i$. é., em face da boa-fé, da razoabilidade e da proporcionalidade jurídicas - satisfatória, senão o recurso à analogia. A necessidade é mãe da ciência... e da ressalva também! 
estabilização dos atos administrativos viciados supostamente por má fé. A propósito é o texto do dispositivo em comento:
“Art. 23. As ações destinadas a levar a efeito as sanções previstas nesta Lei podem ser propostas:
I - até 5 (cinco) anos após o término do exercício de mandato, de cargo em comissão ou de função de confiança;"

Integrativamente, compreendamos o prazo de estabilização dos atos administrativos supostamente viciados por má fé como de cinco anos a contar da saída do agente público ocupante do cargo ou emprego público no qual produziu o ato administrativo que se pretende questionar. Para que se aplique esse prazo, é imprescindível que a vestibular traga razoáveis indícios - lembro que a parte final do art. 54 da Lei n. 9.784/99 emprega a voz "comprovada má fé" para definir o âmbito da ressalva ao prazo comum quiinqiienal - que permitam já numa apreciação perfunctória decidir - certamente não o mérito da demanda - mas, sim, se, no casu, arulta-se justificável o afastamento do prazo prescritivo comum. O que não pode valer, por óbvio, é a mera alegação, em sede exclusivamente discursiva, da suposta presença de má fé. Do contrário, sabido que papel aceita tudo, estaria ensejado ao autor, i.é., à parte prejudicada pela prescrição (a quem interessa, pois, a decretação de sua não intercorrência), definir o prazo prescritivo a que submeteria a sua pretensão anulatória (se quiinqüenal simples ou pela regra da Lei n. 8.429/92, art. 23, l).

A solução, todavia, oferta ainda uma dificuldade: se vários agentes públicos participaram da edição do ato administrativo supostamente viciado por má fé que se pretende invalidar, põe-se o problema de identificar qual será o dies a quo para contagem do prazo prescritivo? Em outras palavras: a partir da saída de qual dos agentes públicos em questão contar-se-ia o prazo de estabilização desse hipotético ato administrativo?

Seja ainda aumentado o problema, envolvendo na hipótese construída o comparecimento de outros sujeitos de direito, favorecidos de alguma forma pelo ato administrativo (pode ser considerar aí, ato em sentido amplo, abarcando assim os bilaterais, notadamente os contratos administrativos).

Muito bem. Várias respostas poderiam ser dadas, a princípio: uma, a partir da data em que ocorrer a primeira saída do cargo por quaisquer dos agentes públicos envolvidos; outra, a partir da data em que o último agente sair do cargo ou emprego público no exercício do qual produziu o ato administrativo; outra ainda, a partir do momento que o terceiro agente público deixar o cargo respectivo e assim por diante...

Obviamente, propender por uma ou por outra, requer uma opção justificável.

Ora, uma premissa sobressai incontornável: para estabilização de um mesmo ato administrativo (unilateral ou bilateral) pelo decurso de tempo, o prazo prescritivo a ser considerado não pode variar de pessoa a outra. Deve ser único. A estabilização é do ato administrativo e em face dele deve ser considerada. Impõe-se como único o prazo prescritivo ainda por decorrência de princípio jurídico próprio ao instituto da prescrição: o da continuidade, segundo o qual tem ela "uma conti- 
nuidade indivisivel: os seus efeitos ativos ou passivos não sofrem solução de continuidade pela substituição de prescribentes ou titulares, em virtude da sucessão universal ou singular." 54

A idéia normativa daí defluida é que não se pode imaginar operáveis distintos prazos prescritivos em relação às várias pessoas que, de alguma forma, participaram da produção de um ato administrativo supostamente viciado ou, de alguma forma, tiveram daí alargado seu patrimônio jurídico ou sofrido um gravame. A anulação do ato administrativo submete-se a um único prazo prescritivo. A suposiçāo ou indício de presença de má fé, no caso, somente se apresenta relevante no que indicado pelo art. 54 da Lei n. 9.784/99, merecer a hipótese a incidência de um prazo prescritivo mais largo - não de vários, nem, muito menos, vários individualmente estimados em face de cada um dos eventuais réus em demandas anulatórias (exclusivas ou cumuladas com outras, como no caso das ações de improbidade administrativa). ${ }^{55}$

Só podendo ser um o prazo em consideração e, a princípio, por um relance d'olhos, podendo-se identificar vários possíveis prazos em vista do, no mínimo, esdrúxulo regramento feito pela Lei n. 8.429/92, art. 23, I, os mesmos fundamentos substanciais éticos e de Justiça que informam os fundamentos do instituto da prescrição não desaparecem na hipótese em causa e, portanto, determinam que a escolha exegética em apreço faça-se fundamentadamente medeada por um juízo de Justiça. E nisso de defender-se um prazo prescritivo único, a ser identificado operando-se o valor de Justiça (eqüidade), para as hipóteses de atos administrativos supostamente produzidos mediante má fé não vai nenhum paradoxo. Também nenhum escândalo pode ser flagrado em se afirmar que aqui comparecem os mesmos princípios substanciais éticos (segurança das relações jurídicas, estabilidade do direito) que subjazem ao instituto em causa. A razão é simples: não há má-fé presumida, não há má fé que preexista a una decisão estatal precedida de devido processo legal; antes disso, há só indício, suposição, hipótese. Demais, por força da natureza abstrata da ação, o fato de sua proposição, o direito de sua proposição, enfim, em nada diz sobre sua procedência (verificação jurisdicional positiva da configuração dos fundamentos da pretensão posta na vestibular).

De meu lado, propendo por adotar, como dies a quo, a data em que o último agente envolvido na produção do ato administrativo que se pretenda invalidar tenha desocupado o cargo ou emprego público que ocupava ao tempo em que expedido o ato administrativo supostamente viciado. Justifico a opção exegética por assim ensejando mais tempo para que os órgãos do sistema jurídico manifestem-se sobre os casos concretos thes submetidos - já a adoção do prazo (mais precisamente dies a quo) do art. 23, I da Lei n. 9.784/92 enseja na imensa maioria dos casos a fluência

54 Antônio Luís da CÂMARA LEAL, Da Prescriçāo e da Decadência, Rio de Janeiro, Forense, 2 ed., 1959, p. 48.

55 E assim se daria mesmo que tentada alguma aproximação com o instituto da prescrição penal, visto que também neste o prazo prescritivo conta-se em relação ao fato idealmente tipicável como crime, sendo um só fato-crime, em face de cada um, somente poderá correr um prazo prescritivo. É o que decorre da própria regência do tema pelos arts. 110 e 111 do Código Penal. 
de um prazo superior ao qüinqüenal —: entre a interpretação que impede a produção de decisão pelo sistema jurídico e outra que, observado um prazo razoável, enseja a persistência da capacidade do sistema jurídico de decidir, esta última parece ser a escolha mais adequada, sobretudo porque referida exegese é construída para o prazo de estabilização do ato administrativo e, não, para o prazo prescritivo da ação de improbidade administrativa. ${ }^{56}$

Cabe, entretanto, apontar um prazo último que impeça a perpetuidade da invalidação dos atos administrativos supostamente viciados, sob pena de sacrifício da segurança jurídica (princípio igualmente caro ao sistema jurídico; aqui o juízo medeado pela eqüidade). Esse papel de prazo último (e, aqui, tão-somente esse papel) para estabilização poderia ser bem desempenhado pelo antigo prazo vintenário inscrito no CC, art. 177, que, entrado em vigor o novo Código Civil, tornou-se decenário, contado a partir da edição do ato administrativo supostamente viciado por má fé. ${ }^{57}$

Quanto aos casos de atos administrativos desfavoráveis aos administrados produzidos em boa fé, estes podem ter o regramento da extinção temporal do acesso ao Judiciário para o fito de sua invalidação remitido ao prazo geral: cinco anos a contar da edição do ato administrativo; aliás, essa é a tônica do Dec. n. 20.910/32, art. $1^{\circ}$.

Há também hipóteses específicas, identificadas em face de previsões explícitas e estritas. É o caso da imprescritibilidade de atos administrativos que supostamente apresentem vícios concernentes à prática de racismo (CF, art. $\left.5^{\circ}, \mathrm{XLII}\right), \grave{a}$ ação de grupos armados contra a ordem constitucional e o Estado Democrático (CF, art. $5^{\circ}$, XLIV) e atos administrativos de registro concernentes ao estado das pessoas físicas (em decorrência de uma principiologia própria desenvolvida em torno dos direitos personalíssimos). Específicos também são os prazos de estabilização previstos no CTN, art. 169 (decisões administrativas irrecorríveis que deneguem a repetição de indébito tributário; prazo de dois anos) e na Lei n. 8.036/90, art. $23, \S 5^{\circ}$ (prescrição trintenária para questionamento de atos administrativos de gestão do FGTS). E certamente outros prazos específicos podem existir por aí ou vir a ser inscritos por normação específica.

Quanto aos atos administrativos configuradores de crimes - aqueles rotulados por Weida Zancaner como absolutamente insanáveis —, em rigor, o tema da estabilização por decurso temporal não os toca por uma razão singela: assim considerados, externam-se esses ditos atos não como atos administrativos (porquanto incapazes de ser interpretados e operados como normas jurídicas), mas como fatos administrativos ou, melhor, pura e simplesmente fatos jurídicos em tese criminosos. Ora, os fatos não são invalidáveis nem convalidáveis - fenômenos operáveis exclusivamente com atos jurídicos ${ }^{58}-\mathrm{e}$, portanto, sequer há sentido em se discutir

56 Para este, outra há que ser a exegese do dispositivo legal em comento, uma vez consideradas as graves implicações sancionatórias envolvidas nessa actio. Para o que deverá ser a exegese também construída com intercedência de juízos de Justiça ou Equiidade.

57 Prazo que caíra para dez anos a partir da vigência do novo Código Civil e seu art. 205.

58 Bem o observa CELSO ANTÔNIO BANDEIRA DE MELLO (Curso..., 13 ed., p. 340): "atos 
sua estabilização (impedimento da invalidação) pelo decurso temporal: como dito, o tema que nos ocupa não os toca.

6. Enfim...

Eis as soluções encontradas e desenvolvidas - sim, desenvolvidas, pois, a exegese de qualquer porção do sistema jurídico não é mero ofício de descobrir verdades lá já existentes e encobertas; tem disso, mas justamente nos casos em que a praxis se acotovela em dificuldades, é que tem mais de construção - para as inconsistências doutrinárias e jurisprudenciais identificadas em apertadíssima síntese face ao espaço compatível com um artigo. Cabe apenas dizer mais o seguinte: partir do encontro de posições jurisprudenciais e doutrinárias que me pareciam insatisfatórias e propor algumas novas posições longe está de afirmar que estas novas afirmações me soem plenamente satisfatórias. Certamente parecem-me menos inconsistentes que aquelas divergidas, daí melhores - razão porque as sustento. A insatisfação, entrementes, permanece e é mesmo pressuposto para aprofundamento e progresso da investigação científica.

administrativos podem ser anulados e revogados, dentro dos limites do Direito; fatos administrativos não são nem anuláveis, nem revogáveis..." 


\section{Tratado de Direito Constitucional Financeiro e Tributário}

\section{Os Direitos Humanos e a Tributação - vol. III}

Imunidades e Isonomia

\section{Ricardo Lobo Torres}

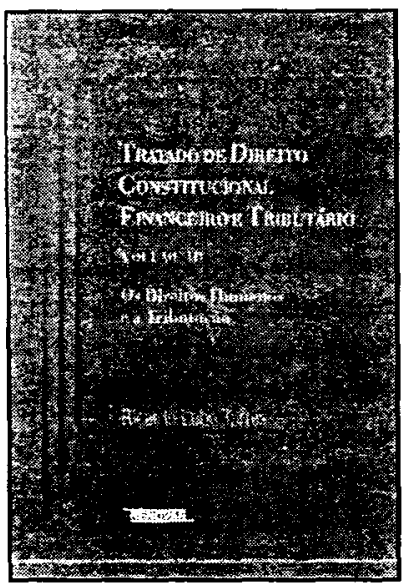

São vistos algums dos aspectos mais relevantes das limitaçòes constitucionais ao poder de tributar. Rediscute-se o problema da proteçào da liberdade fiscal sintetizada nas imunidades a tributos e a impostos que encontram nos direitos humanos o seu fundamento ético e jurídico. Dedica a obra alguns capítulos ao tema da isonomia, que vem recuperando a sua importância após a promulgação da CF de 1988, na qual aparece, sob a forma de proibição de desigualdade, isto é, arbitrariedade, excesso ou desproporção que tornam odiosos os privilégios e as discriminaçōes fiscais.

$\begin{array}{lll}\text { Ref. } 0093 & \text { Encadernado } & 590 \text { págs. } \\ \text { Form. } 16 \times 23 & 1999 & 2^{\underline{a}} \text { ed. }\end{array}$

\section{8-1998: Uma Década de Constituição}

\section{Org. Margarida Maria Lacombe Camargo}

Este livro configura um debate interdisciplinar que comporta o direito, e para o qual concorreram vários autores de prestígio nacional e internacional. Nomes que representam o pensamento jurídico brasileiro e que efetivamente contribuem para o aprimoramento de nossas instituiçōes. Temos certeza de que a difusão que agora se faz contribuirá muito para o enriquecimento do debate nacional e para a formaçāo dos novos juristas.

Ref. 0222

Brochura

Form. 16x23 1999

443 págs.

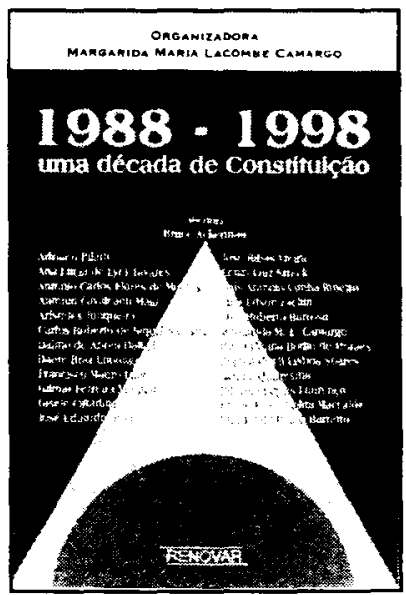

